\title{
71 雑草種の被覆植物としての適合性および土壤保全能力の検討
}

(2)供試雑草の群落構造および地下部の発達と土壤物理性との関係

\section{${ }^{\circ}$ 大嶺 隆 (岡山大・自然科学研究科)・沖陽子(岡山大・環境理工)}

被覆植物は、裸地化した表土を保護し、被覆面の永続的な保護を期待して用いる。しかし、傾 斜面などでは浸食などによる摜乱を受け易いために群落の形成および維持が困難である。そこ で、環境適応力が高い雑草種を選抜し、それらの土壤保全能力の検討を進めている。本報では 雑草種の地上部および地下部の発達が土䁃の物理性に及ぼす影響について検討し、若干の知 見を得たので報告する。

[材料および方法] 岡山大学付属ほ場に植栽枠としてマサ土を充填した斜面枠 $(1 \times 1 \times 0.6 \mathrm{~m}$, 傾 斜角 10 度)を設置し、供試草種にツルニチニチリウ(Vinca major L.), ノ八カタカラクサ(Tradescantia flumiens is Vell.),シロツメクサ(Trifolium repens L.),ギョウギシバ(Cynodon dactylon Pers.)を用いた植栽区に 無植栽の対照区を加えて5処理区を設定した。1996年 7 月に植栽を行い約 1 年間栽培した群落を 対象に、1997年9月に破壊調査を実施し、各処理区1枠づつ解体した。調査方法は植栽枠の中心 に $25 \times 25 \mathrm{~cm}$ のコドラートを 2 個設置し、地上部は $5 \mathrm{~cm}$ 毎に層別刘取りを行い、地下部は土壤深度が 0 から $20 \mathrm{~cm}$ までは $5 \mathrm{~cm}$ 毎に、以下 $50 \mathrm{~cm}$ までは $10 \mathrm{~cm}$ 毎に計 7 層を弪プリングし層別現存量を測定した。 さらに層別の土壤硬度および土性を測定し、あわせて含水比も測定した。なお、土壤水分を均一 にするために調査の1週間前に各植栽枠に 30 リットルの灌水を行った。また、各処理区の地表面と

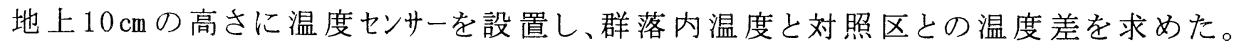

[結果および考察］ 調查時の群落はギョウギシバが被度 100\%で、ツルニチニチりウとノ八カタカラクサは約 $80 \%$ であった。シロツメクサは 6 月頃まで旺盛に繁殖し被度が $100 \%$ あったが、調査時は生育盛期が過ぎ ており約 30\%と低かった。

群落内温度と対照区との温度差を図1に示したところ、どの草種も対照区より低く推移し、その 差は地上 $10 \mathrm{~cm}$ でより大きくなった。特にギョウギシバの地上 $10 \mathrm{~cm}$ は温度差が大きく、最も差が大き いときには $5^{\circ} \mathrm{C}$ 近くも低くなった。次に生産構造についてはギョウギシバが地上 $15 \mathrm{~cm}$ まで茥があり、 この高さを中心に緑葉が分布し他の草種よりも立体的な群落を形成していた(図2)。また、地下部 の層別現存量は、ギョウギシバおよびシロツメクサでは土壤梁度 $50 \mathrm{~cm}$ まで根が存在し、深根性であった

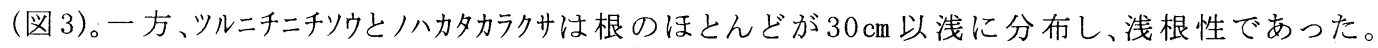

含水比は、対照区で $0 \sim 40 \mathrm{~cm}$ にかけて緩やかに増加し、それから $50 \mathrm{~cm}$ にかけて減少し、同様な 傾向がッルニチニチリウとノ八カタカラクサでも見られた(図 4)。ギョウギシバは 0〜 30 cmまで約 $6 \%$ 付近を推移し たが $30 \mathrm{~cm}$ 以深では急激に低くなった。シロツメクサは 3 \% $4 \%$ と最も低い值を示した。次に土壌硬度は、 どの草種も対照区より高い值を示し、ノ八カタカラクサを除く 3 草種は $30 \mathrm{~cm}$ 以浅でピークがあり、特にッルニ チニチリウの $20 \mathrm{~cm}$ 、シロツメクサの $25 \mathrm{~cm}$ で顕著に高くなった(図5)。全処理区で $40 \mathrm{~cm}$ 以深に増加が見られ たのは自重によって締固められたものと思われた。

細砂の梁度別分布は、対照区では $30 \mathrm{~cm}$ 以深で減少する傾向が見られ、ツルニチニチりウとノ八カタカラ クサでも同様な傾向が認められた（図6)。しかしながら、ギョウギシバおよびシロツメクサは $30 \mathrm{~cm}$ 以深でも 多くの細砂が存在した。また、対照区で0〜 $5 \mathrm{~cm}$ の細砂が他の処理区よりも少なかった。

以上の結果より、植物による被覆は地表面の温度の上昇を軽減させ、さらに高密度の被覆によ って土壤水分が高く保持されることが明らかとなった。また、地下部の発達によって締固めによ る土壤硬度の増加や風化作用の促進といった作用が認められた。そのため、地温上昇の軽減や 土壤水分の保持にはギョウギシバ、土㙵硬度の増加による構造の安定化にはシロツメクサやッルニチニチy ウ、らに風化作用の促進による土壌物理性の向上には深根性のギョウギシバおよびシロッメク少など が適していると示唆された。

Ohmine,T. and Y.Oki : Research on the suitability of weed species as cover plants and their soil conservation abilities. (2)Relation between the soil physical property and the development of productive structure and root system of weed species. 

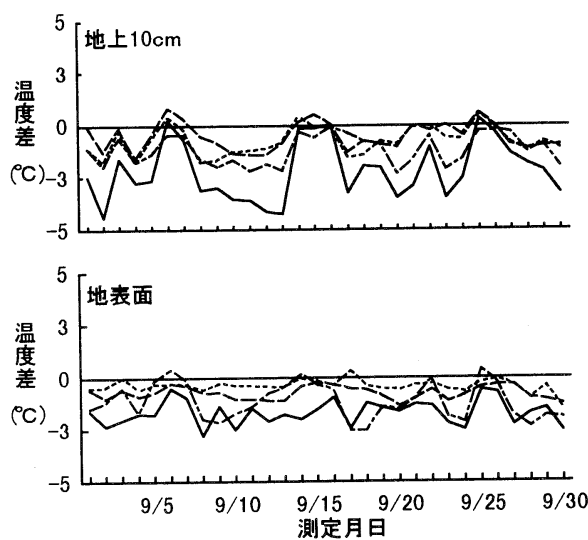

図19月における群落内温度の対照区との温度差

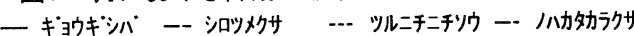
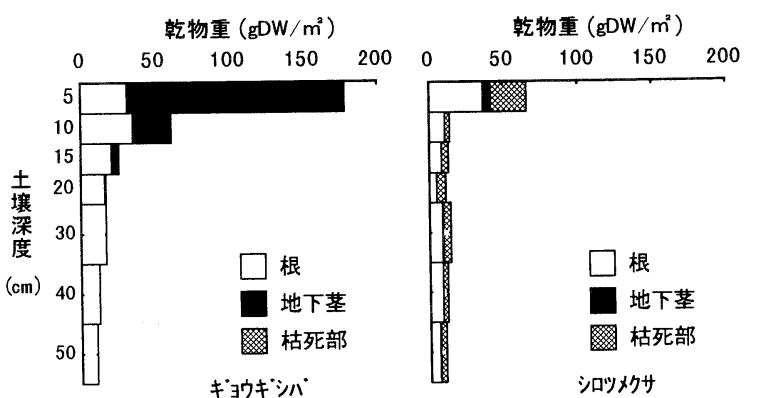

図3 破壊調査時における各供試草種の層別地下部現存量
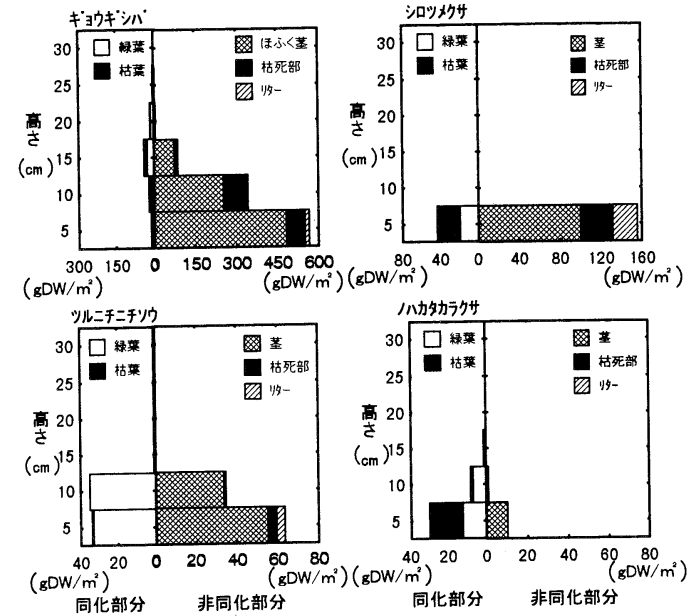

図2 破壊調査時における各供試草種の生産構造図
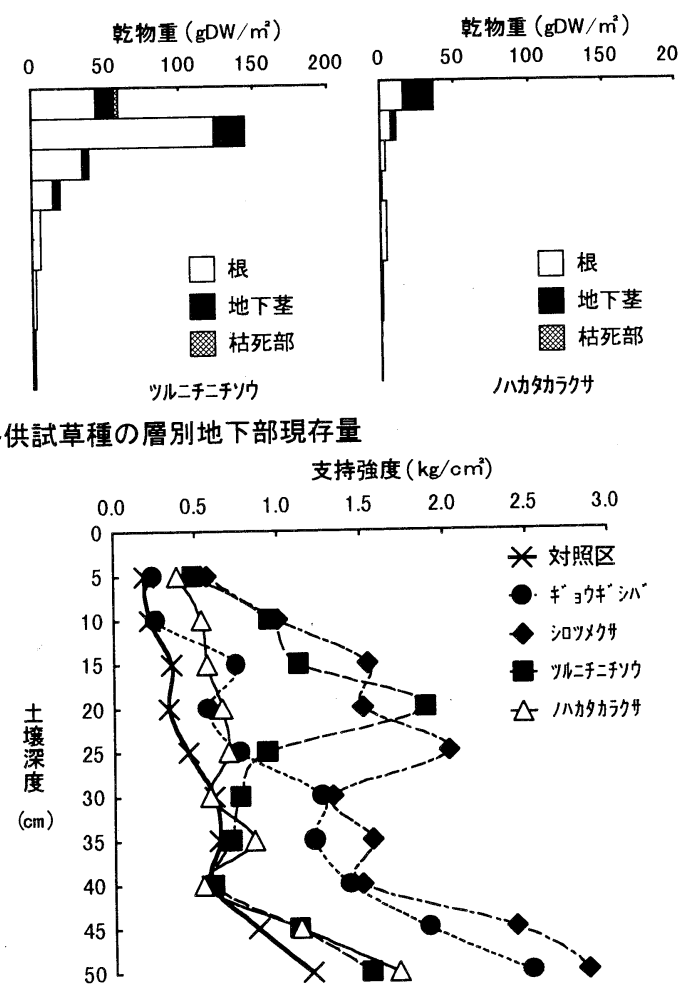

図4 破壊調査時における土壤含水比の深度別分布

図5 破壊調査時における土壌硬度の深度別分布
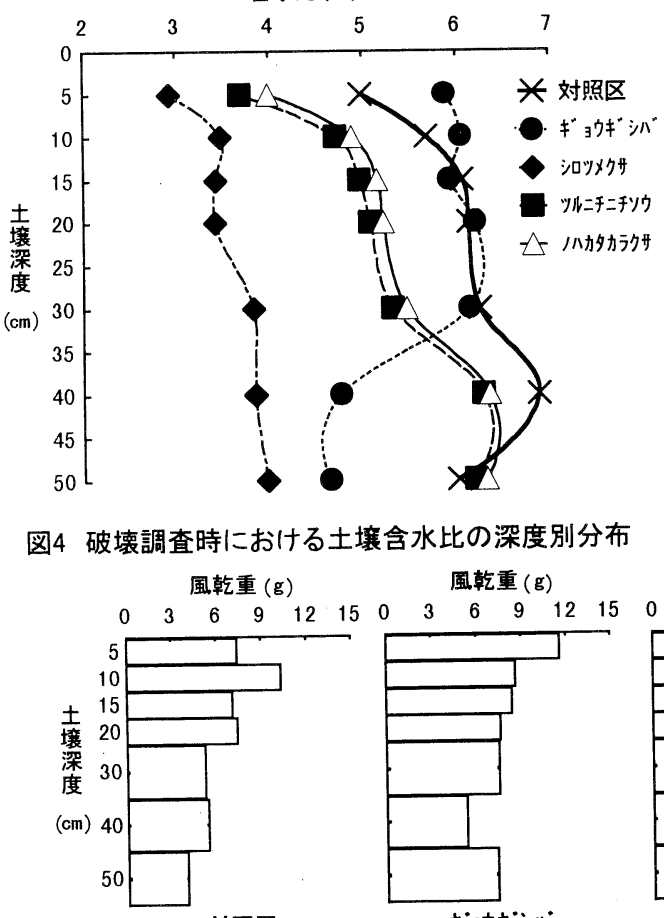

対照区
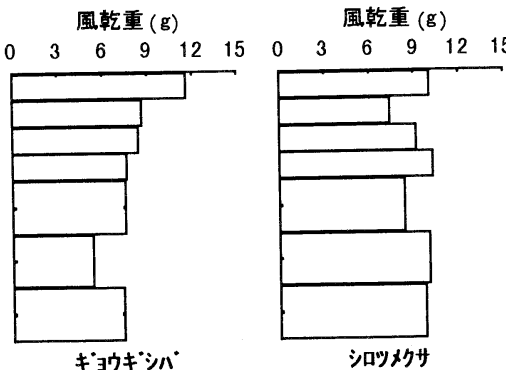

風乾重 $(\mathrm{g})$

風乾重 $(\mathrm{g})$

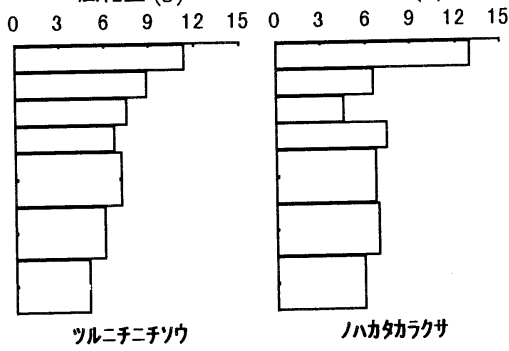

図6 破壊調查時における細砂の深度別分布

注: 細砂(粒径0.2 0.02mm、国際法粒土区分) 


\section{2 水田畦畔に扮ける植物間相互作用の解析}

(1)モデル畦畔の作成および供試植物の特性比較

\section{○中谷敬子・藤井義晴（農環研）}

水田畦畔は刈り取り等の人為的作用の存在下で安定した植生を保ち、生物の多様性 を維持していることが評価されつつある。水田畦畔に扔ける植生の多様性維持機能を 明らかにし、生物多様性にも配慮した植生管理技術の確立に資するため、在来の多年 生草本を組み合わせて植栽した試験用モデル畦畔を作成し、植物群落内の相互作用を 解析する。本報告では、植栽 1 年目の群落における乾物生産特性を検討するとともに、 供試草種の高土壤水分に対する生育反応および他感作用を比較検討したのでその概要 を報告する。

\section{【方 法】}

(1)モデル畦畔植生の作成：農環研試験水田側面に水田用土を用いて幅 $60 \mathrm{~cm}$ 、高さ 25 $\mathrm{cm}$ の畦畔を作成し、在来多年生草本のヨモギ、ミヤコグサ、チガヤ、スギナの 4 草種 の幼苗を図 1 に示す様に組み合わせ、一区6 $0 \mathrm{~cm} \mathrm{x} 60 \mathrm{~cm}$ に 9 個体を配置し、1997年 7 月16日に植栽した。同年 10 月 8 日に地上部の刈り取りを行い、各草種ごとの乾物生 産量を処理区間で比較検討した。

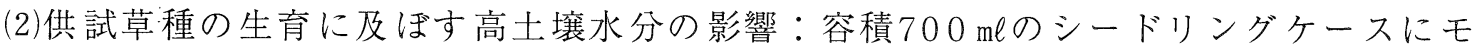
デル畦畔作成に用いた土壤を充填し、土壤水分を図 2 に示す 4 段階に調節し、供試 4 草種の地下部繁殖器官を埋土し、気温 $25^{\circ} \mathrm{C} 12$ 時間明条件のファイトトロン内に設置 した。処理開始後39日に器官別の生育量を個体ごとに調査した。

(3)供試草種の他感作用：供試 4 草種について、プラントボックス法により根から分泌 される物質の他感作用を、サンドイッチ法により葉から溶出する物質の他感作用を、 ともに催芽処理したメヒシバ種子を検定植物として用い、単一草種および 2 草種混合 で比較検討した。

\section{【結果および考察】}

(1)モデル畦畔における各処理区の地上部乾物重はヨモギを植栽した区で大きく、個体 別の地上部乾物重もヨモギが他草種と比較して大きかったが、ヨモギの生育は混植し た他草種の影響を大きく受け、2 草種混植区でスギナを混植した場合、それ以外草種 の場合と比較して、生育が抑制される傾向が認められた（図 1 ）。

(2) ヨモギ、チガヤの生育、特に地下部繁殖器官の形成は高土壤水分の影響を大きく受 け、 $84 \%$ 以上の含水比でヨモギは枯死し、チガヤの根茎形成・伸長量は大きく減少 した。これに対し、スギナおよびミヤコグサの生育は高土潩水分の影響を受けにくく、 特にスギナは湛水条件下で萌芽が認められなかったが、塊茎は枯死せず、処理期間後 の萌芽試験で $100 \%$ の萌芽率を示した（図 $2 、 3 ） 。$

(3)プラントボックス法およびサンドイッチ法による検定結果から、供試各草種単独の 場合より、2 草種を混合した場合の方がメヒシバの幼根伸長を阻害する活性が高いこ とが示された（図4，表1）。

以上から、畦畔植生に扔ける供試各草種の環境適応性の差異の一部が明らかになる とともに、草種の共存により群落内の他感作用性が高まる可能性が示唆された。今後 は刚り取り等の人為的作用が畦畔植生の群落構造に及ぼす影響を解析する予定である。

Nakatani,K. and Y.Fujii : Plant interaction in vegetation of a model levee. 


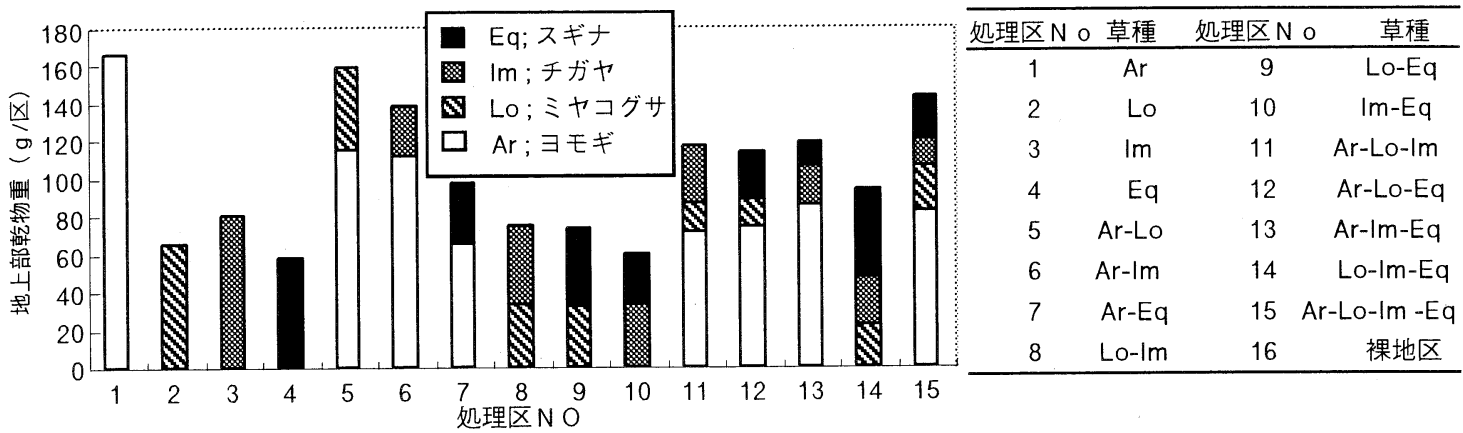

図 1 モデル畦畔における供試植物の地上部乾物重

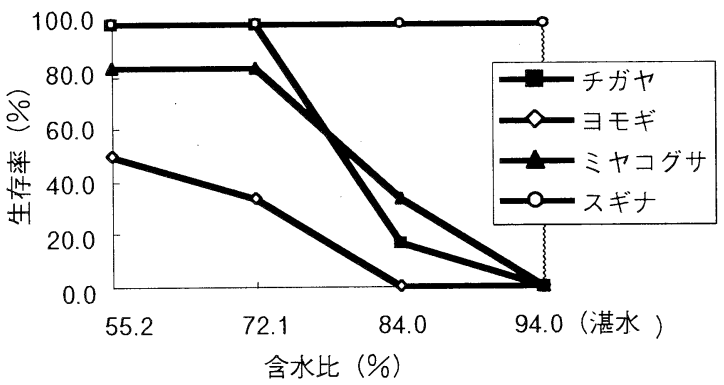

図 2 供試植物生存率に及ぼす土壤水分の影響

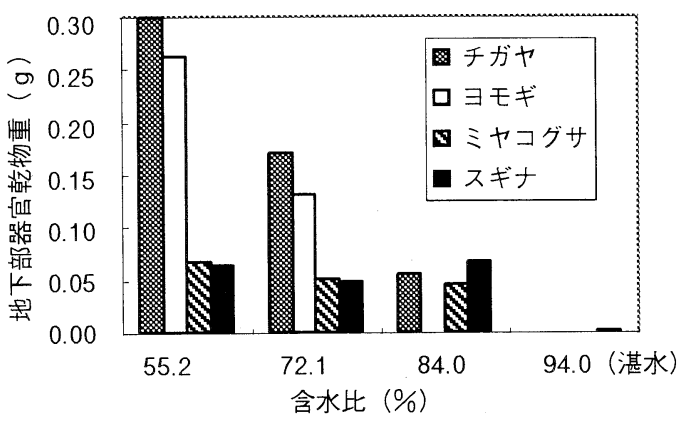

図 3 地下部器官形成に及ぼす土壤水分の影䇒

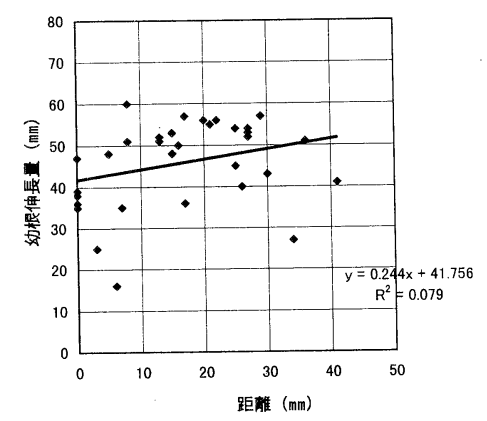

(a)ヨモギ

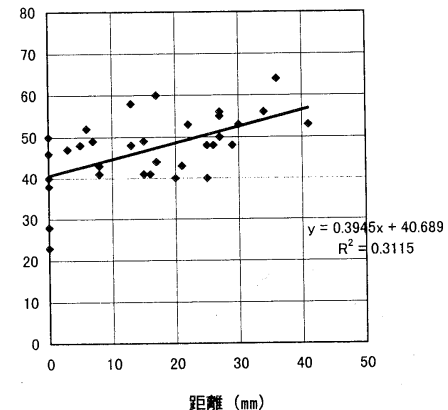

(b)チガヤ

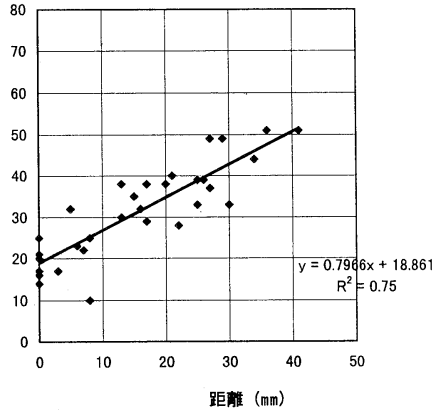

(c)ヨモギ十チガヤ

図 4 他感作用性における供試植物混合の効果（プラントボックス法；検定植物：メヒシバ，幼根伸長）

$\frac{\text { 表 } 1 \text { メヒジの幼根伸長に及ぼす供試草種の他感作用性 1) }}{\text { プラントボックス法検定結果 }}$

\begin{tabular}{|c|c|c|c|c|c|}
\hline 供試 草種 & 回帰線の傾き & 相関係数 & $\begin{array}{l}\text { メヒシバ幼根伸長 } \\
\text { cont比 }(\%)\end{array}$ & \multicolumn{2}{|c|}{ 供試葉量 $10 \mathrm{mg} \mathrm{DW} / 10 \mathrm{~cm}^{2}{ }^{2}$ 供試葉量 $\left.50 \mathrm{mg} \mathrm{DW} / 10 \mathrm{~cm}^{2} 3\right)$} \\
\hline ヨモギ & 0.189 & 0.208 & 94.4 & 56.5 & 47.9 \\
\hline ミヤコグサ & 0.278 & 0.366 & 91.9 & 50.6 & 41.7 \\
\hline チガヤ & 0.442 & 0.502 & 84.9 & 78.0 & 53.1 \\
\hline スギナ & 0.446 & 0.488 & 83.8 & 69.6 & 50.0 \\
\hline ヨモギ・ミヤコグサ & 0.389 & 0.641 & 84.5 & 43.8 & 26.4 \\
\hline ヨモギ・チガヤ & 0.722 & 0.753 & 50.6 & 66.6 & 40.6 \\
\hline ヨモギ・スギナ & 0.491 & 0.521 & 67.2 & 64.7 & 42.1 \\
\hline ミヤコグサ・チガヤ & 0.331 & 0.461 & 80.5 & 42.5 & 31.5 \\
\hline ミヤコグサ・スギナ & 0.568 & 0.672 & 66.1 & 39.9 & 35.5 \\
\hline チガヤ・スギナ & 0.533 & 0.619 & 69.6 & 65.4 & 37.6 \\
\hline
\end{tabular}

1) 表中の值は 3 反復の平均値を示した。

2) 供試葉量は単独草種の場合 $10 \mathrm{mg} 、 2$ 草種混合は 1 草種あたり $10 \mathrm{mg} 、$ 合計 $20 \mathrm{mg}$ とした。

3）供試葉量は単独草種の場合 $50 \mathrm{mg} 、 2$ 草種混合は 1 草種あたり $25 \mathrm{mg} 、$ 合計 $50 \mathrm{mg}$ とした。 


\section{3 畑作におけるカバークロップ利用による雑草管理法}

\section{。佐合隆-...Atawong Anotai（茨城大学農学部）}

夏作物の前作に地力向上効果と雑草抑止効力を目的にカバークロップを導入する栽培法の基 本的問題点を明らかにするため、へアリベッチを秋冬期の休䦥期に時期を変えて播種し、へア リベッチの生育量と雑草発生抑止力の関係及び作物との競合実態などについて調查した。

\section{実験材料および方法}

1996年から1997年に茨城大学農学部附属農場において実施した。試験区は1区4.5m x 9mの 3連制とし、ヘアリベッチを1996年10月7日、26日、11月15日および1997年3月15日播種した。 その後試験区を2分割してトウモロコシを4月24日、大豆を5月15日に播種した。10月7日と26 日播種区は除草剤ビアラホス500ml/10aを1001/10aの水量で、トウモロコシ区は4月13日に 大豆区は5月5日散布して、ヘアリベッチと雑草を枯殺した。作物の播種密度はトウモロコシで 条間 $90 \mathrm{~cm}$ 、株間 $30 \mathrm{~cm}$ とし、大豆で条間 $60 \mathrm{~cm}$ 、株間 $20 \mathrm{~cm}$ とし、出芽後間引き1本仕立てとし、 作物は無肥料で栽培した。雑草およびヘアリベッチは被度、地上部生体重を大豆、トウモロコ シは生育、収量などを調查した。

\section{結果および考察}

ヘアリベッチの冬生雑草に対する発生抑制效果は10月26日播種区で最も高く、次いで10月7 日播種区で高く、11月15日播種区は最も低かった。复生雑草の発生抑制効果は10月7日播種区 で最も高く、10月26日播種区が最も低かった。11月15日および3月15日播種区のへアリベッチ は作物の播種時には作㧛上支障のない生育量であったが、作物の出芽後は競合し、作物の生育 を著しく抑制した。ヘアリベッチの生体および枯死体は、作物の発芽には影響を示さなかった。
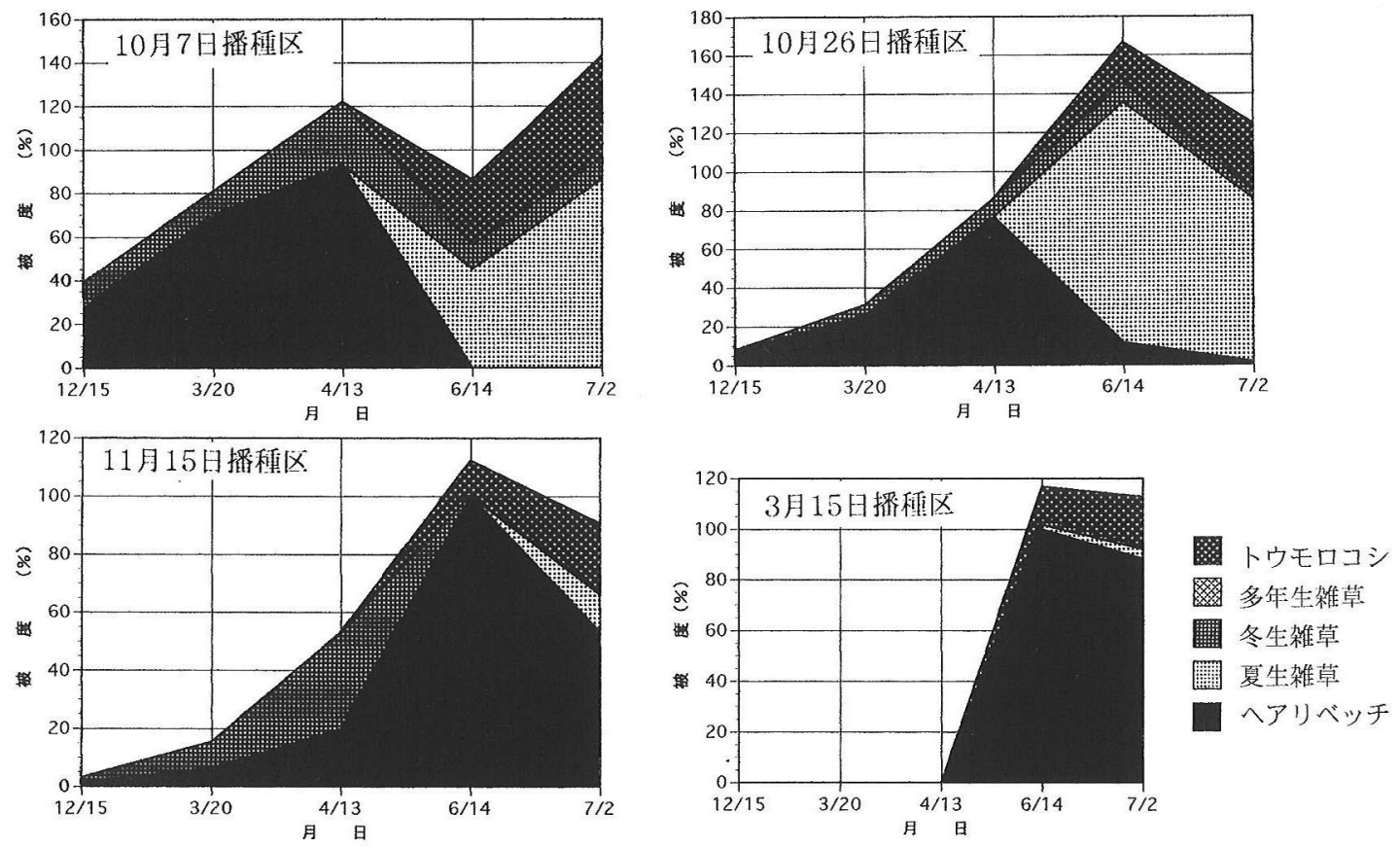

第1図 トウモロコシ灯（1月24月䍜和）における被度の推移

Sago,R.,A.Atawong: Principles of Weed Control for Field Crops Production with Cover Crops 

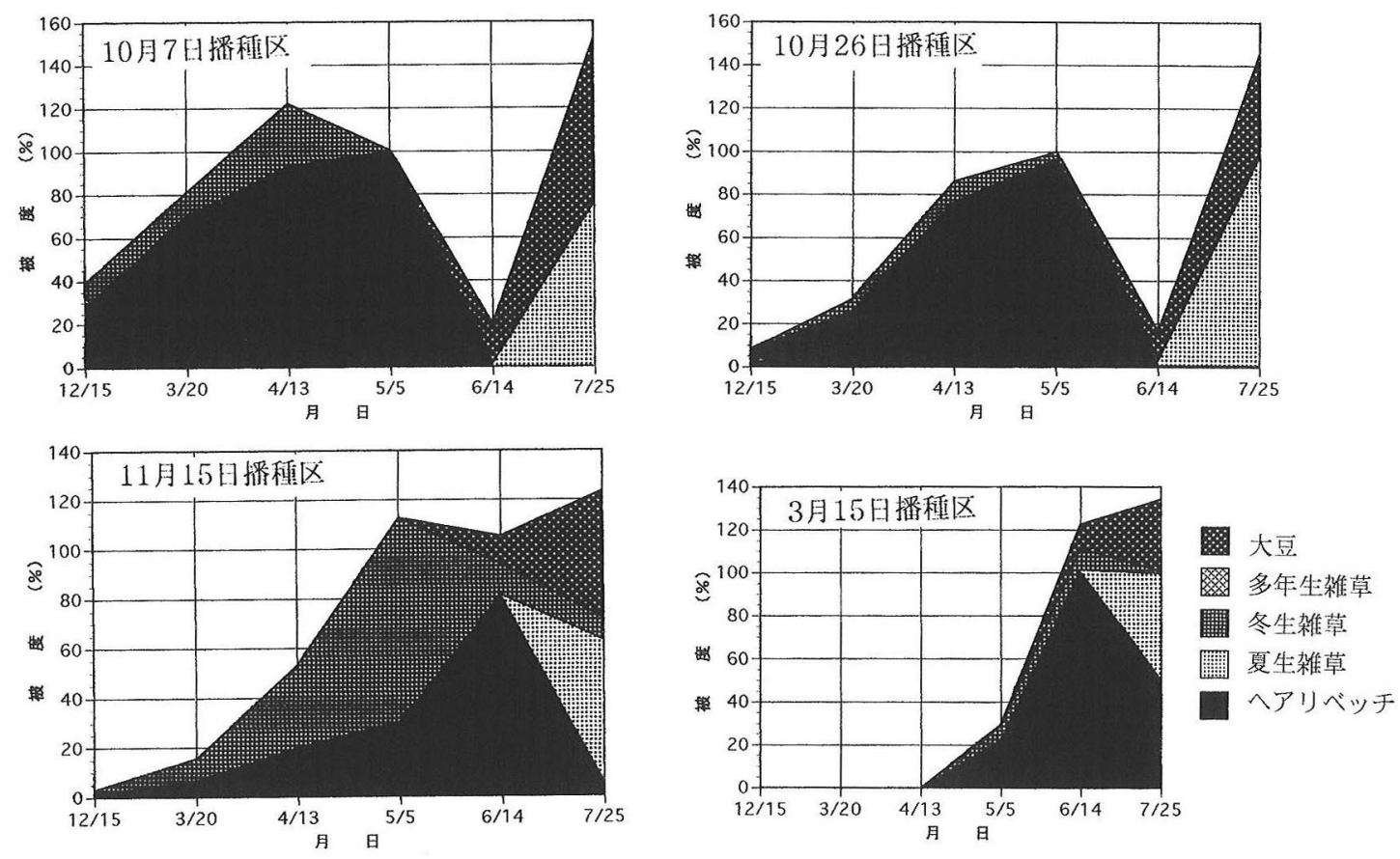

第2図 大豆畑（5月15日播碩）における被度の推移

第1表 トウモロコシの生育調査結果

\begin{tabular}{|c|c|c|c|c|c|c|c|}
\hline \multirow{2}{*}{ 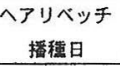 } & \multirow{2}{*}{$\begin{array}{l}\text { トウモロコシ } \\
\text { 出芽率 }(\%)\end{array}$} & \multicolumn{3}{|c|}{ 草丈 (c m) } & \multicolumn{2}{|c|}{ 地上部生体重（g/株） } & \multirow{2}{*}{$\frac{\text { 子実重 } \mathrm{g} / \text { 棁 }}{7 \text { 月2日 }}$} \\
\hline & & 5月29日 & 6月15日 & 7月2日 & 6月15日 & 7月2日 & \\
\hline 10月7日 & 82.7 & 39.0 & 64.9 & 129.3 & 91.3 & 476.5 & 210.5 \\
\hline 10月26日 & 85.9 & 33.0 & 45.0 & 99.3 & 44.9 & 227.1 & 87.7 \\
\hline 11月15日 & 87.3 & 27.3 & 26.6 & 76.2 & 8.5 & 108.1 & 52.4 \\
\hline 3月15日 & 88.6 & 27.0 & 33.7 & 114.3 & 13.1 & 137.5 & 53.3 \\
\hline 手取除草区 & 88.9 & 25.7 & 40.2 & 107.2 & 33.7 & 282.2 & 132.9 \\
\hline $\mathrm{F}$ 値 & & 4.8 & 8.3 & & 4.9 & 7.6 & 7.0 \\
\hline $\mathrm{P}<0.05 \%$ & & $*$ & $*$ & & * & $*$ & * \\
\hline
\end{tabular}

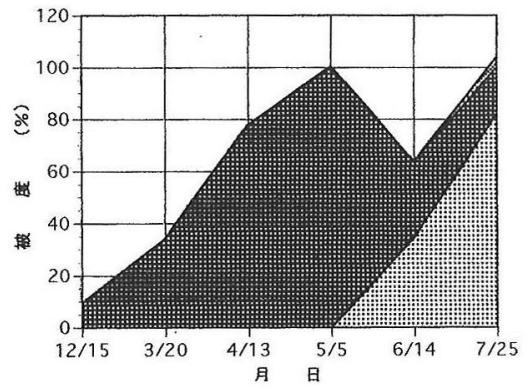

第3図 無処理区の被度の推移

第2表 大豆の生育調查結果

\begin{tabular}{|c|c|c|c|c|c|c|c|c|}
\hline \multirow{2}{*}{$\begin{array}{c}\text { ヘアリベッチ } \\
\text { 播種日 } \\
\end{array}$} & \multirow{2}{*}{$\begin{array}{c}\text { 大豆 } \\
\text { 出芽率 (\%) }\end{array}$} & \multicolumn{3}{|c|}{ 草丈 $(\mathrm{c} \mathrm{m})$} & \multicolumn{3}{|c|}{ 地上部生体重 ( $\mathrm{g} /$ 株) } & \multirow{2}{*}{$\begin{array}{c}\text { 子実重 } \mathrm{g} \text { （株） } \\
8 \text { 月1日 } \\
\end{array}$} \\
\hline & & 6月14日 & 7月5日 & 7月25日 & 6月15日 & 7月5日 & 7月25日 & \\
\hline 10月7日 & 90.5 & 22.9 & 50.3 & 57.8 & 4.4 & 66.6 & 134.2 & 103.3 \\
\hline 10月26日 & 89.1 & 23.0 & 46.5 & 53.8 & 4.3 & 39.7 & 131.7 & 43.3 \\
\hline 11月15日 & 81.1 & 27.8 & 48.4 & 50.6 & 3.4 & 37.0 & 109.0 & 47.9 \\
\hline 3月15日 & 84.4 & 27.6 & 49.1 & 53.0 & 3.8 & 33.1 & 94.0 & 52.8 \\
\hline 手取り除草 & 90.7 & 17.5 & 45.6 & 51.9 & 4.5 & 60.3 & 149.3 & 87.9 \\
\hline $\mathrm{F}$ 值 & & 13.4 & & & & & & 12.8 \\
\hline$P<0.05 \%$ & & $*$ & & & & & & $*$ \\
\hline
\end{tabular}

作物の生育量、子実重量が最も高かったのは10月7日播種 区であり、完全除草区を上回った。ヘアリベッチの雑草 抑制効果は雑草の発生消長によって影響を受け、冬生雑草 の発生ピークの10月上句、复生雑草の発生ピークの5月中 旬における除草(耕種)作業、ヘアリベッ于の生育量(枮死株 のマルチ効果)や作物の生育量(被陰効果)が雑草害回避の重

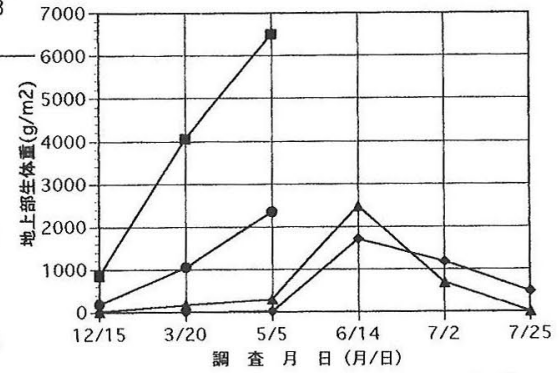

第4図 ヘアリベッチの生体重の推移 要な要素となった。 


\section{4 地被植物の植栽による畦畔植生省力管理法 第 1 報 利用可能な草種の選定}

保科亭・前田光裕（広島県立農業技術センター）

中山間地域では棚田が多く，畦畔管理に関わる労働負担が大きい。特に，急傾斜地では基盤 整備に伴い法面部分が非常に大きくなり，刈払い等の従来の方法では管理が困難となっている。 そこで, 演者らは地被植物で畦畔を覆うことによって雑草の発生を抑制する省力的な管理法に ついて検討している。本報では 46 の草種について生育特性を調査し, 地被能力を主な指標と して利用可能な草種の選定を行った。

\section{[材料及び方法]}

試験 I 高冷地研究部 (広島県山県郡大朝町, 標高 $400 \mathrm{~m}$ ) 内に 1995 年 4 月に造成した試験用 畦畔 (黒ボク土, 長さ $50 \mathrm{~m}$, 高さ $80 \mathrm{~cm}$, 法面幅 $120 \mathrm{~cm}$ ) において, アークトテカ, マツバギ ク，シバザクラ（品種名：スカーレット），アジュガの 4 種を，1995 年 5 月 24 日に $30 \times 30$ $\mathrm{cm}\left(11.1\right.$ 株 $\left./ \mathrm{m}^{2}\right)$ の栽植密度で定植を行った。定植時に, 肥効調節型肥料（セラマイティー U 1 号®) を 1 株当たり窒素成分で $1.5 \mathrm{~g}$ となるよう施用した。定植後, 被度の推移を調查した。 なお, 1996 年 7 月, 1997 年 5 月, 7 月, 10 月に全面手取り除草を行った。

試験 II 高冷地研究部内の水田転換畑において, 46 草種（表 1）を1996 年 4 〜 月に 11.1 株/ $\mathrm{m}^{2}$ の栽植密度で定植し（アークトテカのみ 1997 年 6 月に再定植）, 被度, 草高, 開花等を調 查した。なお, 雑草による影響を避けるため, 適宜手取り除草を行った。

\section{[結果および考察]}

試験 I (図 1 ) アークトテカは地被能力が高く, 初年目の定植後45 日にほぼ全面を被覆し た。耐寒性がやや弱く，冬季に地上部のほとんどが枯死したが，2 年目の 4 月上旬に越冬茎か らの萌芽が始まり，7 月上旬に全面を被覆した。しかし，3 年目は前 2 年に比べ生育がやや緩 慢であった。シバザクラは, 初年目は被度が低かったが, 耐寒性が極めて強く 2 年目以降順調 に被度が上昇し，3 年目にほぼ $100 \%$ に達した。マツバギクは，初年目は生育が良好で定植後 100 日で全面を被覆したが，耐寒性が弱く，低温によると思われる枯死株が発生し，3年目に 全ての株が消失した。アジュガは耐寒性は強いものの，3年間を通じて生育は低調であった。 以上の結果, アークトテカは地被能力が極めて高く有望であるが, 耐寒性が弱いため, 温暖地 に適していると考えられる。シバザクラ類は被覆を形成するまでやや期間を要するが，耐寒性 が強く群落も安定しており, 寒冷地を中心に有望である。

試験 II （表 1 ） 地被能力や耐寒性の面から寒冷地で有望な草種は, コウリンタンポポ, ロー マンカモミール, セイヨウノコギリソウ, ブタナ, シバザクラ類, ヒペリカム・カリシナム, ビンカ・マジョール, ビンカ・ミノール, ヘビイチゴ, ポテンティラ, ツルマンネングサ, メ キシコマンネングサの 21 種であった。標高の低い温暖地域で有望な草種はアークトテカ, ウ エデリア, サッマノギク, マツバギク, バーベナ類, イモカタバミ, リーシマキア, ギンパイ ソウの 9 種であった。以上の有望草種の中で, 着花密度や開花期間などの開花特性から, 景観 形成面で優れる草種はシバザクラ類, マツバギク, バーベナ類, イモカタバミ, ギンパイソウ の 15 種であった。また, シバザクラ類は品種によって地被能力, 耐湿性, 花色, 開花期間な どの特性が異なるため, 品種間差を考虑して適応性を検討する必要がある。

Hoshina,T. and M.Maeda : Weed management on the levee of rice fields by the use of ground cover plants (1) Screening of ground cover plants 


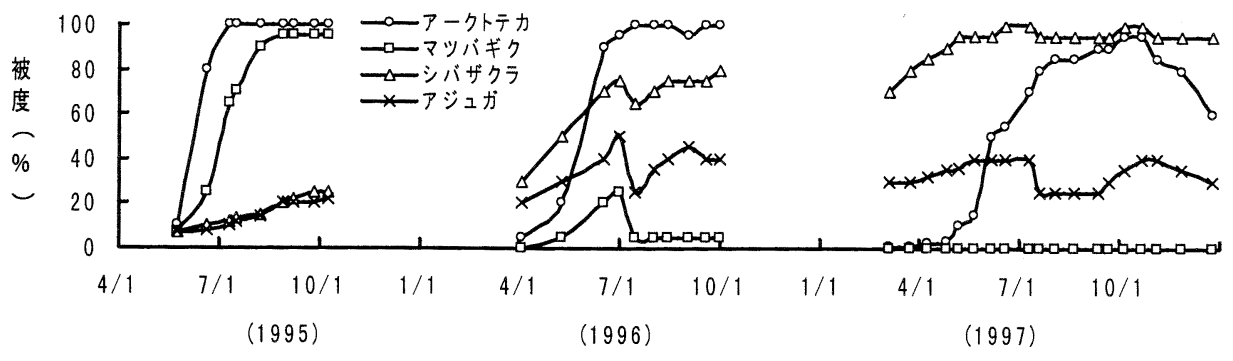

図 1 畦畔に定植した地被植物の被度の推移（1995～1997）

表 1 試験に供試した地被植物の生育特性 (1996～1997)

\begin{tabular}{|c|c|c|c|c|c|c|c|c|c|c|}
\hline \multirow[b]{2}{*}{ 供 試 草 種 } & \multirow[b]{2}{*}{ 名 } & \multicolumn{2}{|r|}{ 被度 } & \multicolumn{2}{|l|}{$(\%)$} & \multirow[b]{2}{*}{$\begin{array}{r}\text { 草高 } \\
\text { cm }\end{array}$} & \multirow[b]{2}{*}{$\begin{array}{l}\text { 地被 } \\
\text { 能力 }\end{array}$} & \multirow[b]{2}{*}{$\begin{array}{c}\text { 耐寒 } \\
\text { 性 }\end{array}$} & \multirow[b]{2}{*}{ 開花期間 } & \multirow[b]{2}{*}{$\begin{array}{l}\text { 着花 } \\
\text { 密度 }\end{array}$} \\
\hline & & $\frac{1996}{10 / 16}$ & $3 / 5$ & $\frac{1997}{6 / 19}$ & $10 / 22$ & & & & & \\
\hline アークトテカ & キク & 100 & 0 & 30 & 100 & 20 & (2) & $\Delta$ & $5 /$ / 11/中 & 中 \\
\hline ガザニア（ユニフロラ） & キク & 40 & 0 & 0 & 0 & - & $x$ & $x$ & 5/中～11/上 & 中 \\
\hline コウリンタンポポ & キク & 95 & 60 & 90 & 90 & 15 & 0 & (2) & $5 /$ 下 11/上 & 疎 \\
\hline ローマンカモミール & キク & 85 & 50 & 100 & 100 & 50 & (2) & (2) & 6/中 10/中 & 中 \\
\hline ウエデリア & キク & 100 & 0 & 0 & 0 & - & (2) & $x$ & $6 /$ 中 10/中 & 中 \\
\hline セイヨウノコギリソウ & キク & 50 & 50 & 100 & 100 & 80 & (2) & $\mathrm{O}$ & 5/下 8/下 & 密 \\
\hline ブタナ & キク & 5 & 15 & 95 & 50 & 28 & 0 & 0 & $6 /$ 上 10/中 & 中 \\
\hline サツマノギク & キク & 9 & 2 & 35 & 100 & 90 & 0 & $\Delta$ & $11 /$ 上 12/上 & 密 \\
\hline シバザクラ（オータムローズ） & ハナシノブ & 50 & 70 & 100 & 100 & 19 & 0 & (a) & $4 /$ 下 5/下 & 密 \\
\hline シバサクラ（スカーレット） & ハナシノブ & 95 & 95 & 75 & 100 & 25 & (2) & () & 4/中〜 $6 /$ 上 & 密 \\
\hline シバザクラ（ダニエルクッション） & ハナシノブ & 55 & 70 & 100 & 100 & 22 & 0 & (c) & 4/上〜 6/中 & 密 \\
\hline シバザクラ（モンブラン ） & ハナシノブ & 70 & 80 & 90 & 95 & 28 & 0 & (2) & $4 /$ 上 6/上 & 密 \\
\hline シバザクラ（タマノナガレ） & ハナシノブ & 60 & 65 & 70 & 95 & 18 & 0 & (0) & $4 /$ / $\sim 5 /$ 中 & 密 \\
\hline シバザクラ（ユウフジナミ） & ハナシノブ & 75 & 75 & 100 & 100 & 30 & () & (0) & $4 /$ 上 6/上 & 密 \\
\hline シバザクラ[ピンク] & ハナシノブ & 100 & 100 & 75 & 90 & 32 & (2) & (0) & 4/下〜 6/上 & 密 \\
\hline シバザクラ〔レッド〕 & ハナシノブ & 90 & 100 & 100 & 100 & 30 & (2) & (0) & $4 /$ 上 6/上 & 密 \\
\hline シバザクラ[パープル] & ハナシノブ & 45 & 45 & 85 & 100 & 25 & 0 & (0) & $4 /$ / $\sim 6 /$ 中 & 密 \\
\hline シバザクラ〔ホワイト〕 & ハナシノブ & 100 & 100 & 100 & 100 & 32 & ()) & () & 4/上～6/中 & 密 \\
\hline マツバギク & ザクロソウ & 95 & 20 & 100 & 40 & 25 & (2) & $\Delta$ & $6 /$ 上 $11 /$ 下 & 密 \\
\hline アジュガ & シソ & 2 & 1 & 12 & 45 & 10 & $\Delta$ & 0 & 4/下〜 6/中 & 密 \\
\hline イブキジャコウソウ & シソ & 50 & 20 & 55 & 10 & 20 & $\Delta$ & $\Delta$ & $6 /$ 上 $11 /$ 上 & 中 \\
\hline ラーミウム & シソ & 65 & 35 & 65 & 60 & 40 & $\Delta$ & $\Delta$ & $5 /$ 上 5/中 & 疎 \\
\hline ローズマリー〔這性〕 & シソ & 85 & 0 & 0 & 0 & - & 0 & $x$ & - & - \\
\hline バーベナ (タピアン) & クマッヅラ & 100 & 0 & 0 & 0 & - & (2) & $x$ & 4/下 11/中 & 密 \\
\hline バーベナ（テネラ） & クマッヅラ & 100 & 0 & 0 & 0 & - & (0) & $x$ & 5/中〜11/中 & 密 \\
\hline イベリス（センペルビレンス） & アブラナ & 70 & 40 & 85 & 50 & 26 & $\Delta$ & 0 & $4 /$ / $~ 6 /$ 下 & 中 \\
\hline ヒペリカム・カリシナム & オトギリソウ & 100 & 95 & 100 & 100 & 63 & (a) & 0 & $6 /$ 中 $10 /$ 上 & 踈 \\
\hline イモカタバミ & カタバミ & 90 & 30 & 95 & 70 & 20 & 0 & $\triangle$ & $5 /$ 上 $11 /$ 上 & 密 \\
\hline テイカカズラ & キョウチクトウ & 40 & 30 & 12 & 25 & 20 & $\Delta$ & $\Delta$ & - & - \\
\hline ビンカ・マジョール & キョウチクトウ & 95 & 95 & 100 & 100 & 60 & (a) & 0 & $4 /$ / $~ 6 /$ 中 & 疎 \\
\hline ビンカ・ミノール & キョウチクトウ & 30 & 50 & 80 & 100 & 27 & 0 & 0 & $4 /$ 上 6/上 & 疎 \\
\hline リーシマキア & サクラソウ & 50 & 10 & 90 & 100 & 12 & 0 & $\Delta$ & 5/中～ 6/中 & 中 \\
\hline アベリア（エドワードゴーチャ） & スイカズラ & 60 & 1 & 45 & 90 & 57 & 0 & $\triangle$ & 7/上～10/上 & 中 \\
\hline ギンパイソウ & ナス & 85 & 0 & 100 & 100 & 12 & 0 & $\Delta$ & 6/上〜 8/中 & 密 \\
\hline ダイアンサス（アルベルネンシス） & ナデシコ & 0 & 0 & 0 & 0 & - & $x$ & $?$ & 5/中〜 5/下 & 中 \\
\hline ダイアンサス（ライオンロック） & ナデシコ & 10 & 1 & 2 & 5 & 12 & $x$ & $?$ & - & - \\
\hline ヘビイチゴ & バラ & 100 & 50 & 90 & 95 & 12 & 0 & 0 & 5/上〜 6/中 & 中 \\
\hline ポテンティラ & バラ & 100 & 40 & 100 & 100 & 18 & (0) & $\mathrm{O}$ & 5/中〜 11/下 & 中 \\
\hline ルプスカリシノイデス & バラ & 15 & 10 & 35 & 25 & 17 & $x$ & $\Delta$ & - & - \\
\hline セダム & ベンケイソウ & 15 & 5 & 10 & 10 & 10 & $x$ & $\Delta$ & - & - \\
\hline ツルマンネングサ & ベンケイソウ & 85 & 65 & 100 & 95 & 17 & 0 & 0 & $6 /$ 上 6/下 & 中 \\
\hline メキシコマンネングサ & ベンケイソウ & 95 & 85 & 45 & 100 & 20 & 0 & 0 & $6 /$ 上 7/下 & 中 \\
\hline キツネノカミソリ & ヒガンバナ & 1 & 2 & 5 & 1 & 15 & $x$ & 0 & - & 中 \\
\hline ナツズイセン & ヒガンバナ & 0 & 0 & 5 & 0 & 43 & $x$ & $\Delta$ & $8 /$ 上 & 中 \\
\hline ヒガンバナ & ヒガンバナ & 5 & 10 & 5 & 5 & 19 & $\Delta$ & 0 & $9 /$ 中 10/上 & 中 \\
\hline リュウノヒゲ & ユリ & 10 & 5 & 15 & 20 & 13 & $x$ & 0 & - & - \\
\hline
\end{tabular}

注1)供試草種は属・種，（）内は品種名，〔]内は特性を示す $\quad 2 ）$ 草高は1997年中の最高値 3$)$ 地被能力及び耐寒性, 着花密度は 達観による 4) 地被能力, 耐寒性の記号は ( ) : 高, 強, ○ : やや高, やや強, $\Delta:$ 中, $\times$ : 低, 弱, ? : 不明を示す 


\section{5 ヘアリーベッチを利用した休耕田の管理}

○藤原伸介・花野義雄・藤井義晴 ${ }^{*}$ （四国農試 $\cdot^{*}$ 農環研）

【目的】マメ科牧草のヘアリーベッチは春から初夏にかけての雑草抑制に優れた効 果を持つため、果樹園の下草として、また休耕地や耕作放棄地の省力的な雑草管理に 適した植物として、近年全国各地で普及しつつある。一方、ヘアリ一ベッチは枯れた 後もしばらくの間雑草を抑えるものの、8月以降の雑草発生に未だ問題が残っている。 本報では、休耕田にすき込んだ後すぐに湛水したときのへアリーベッチの抑草効果に ついて報告する。

\section{【材料および方法】}

耕作放棄水田にヘアリーベッチを秋撒きし、翌年 5 月末、ヘアリーベッチの最盛期

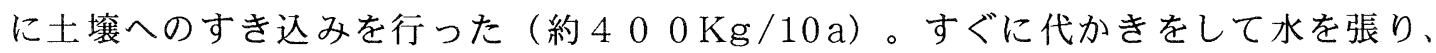
ベッチの代わりに雑草をそのまますき込んだ対照区とその後の雑草植生の比較調査を 行った。また、ベッチすき込み区の田面水自身に抑草作用があるかどうかを調べるた め、すき込み 1 週間後の田面水を寒天で固化させ、ファイトトロン内で水田より採取 したアゼナの寒天上での生育試験を行った。

【結果および考察】

ヘアリーベッチを秋撒きした場合、翌年 5 月時点での雑草抑制力は、これまでの観 察と同様非常に強く、バイオマス量においてもクローバーやレンゲ等のマメ科緑肥を 大きく上回った（図 1) 。ただ、ベッチをすき込まず枯れた後もそのままの放置状態 にすると、9月には相当量の雑草繁茂が見られた（図 2)。他方、5月のベッチ最盛 期に土壌中にすき込んだ後湛水条件にすると、すき込み後しばらくして著しいガスの 発生が認められ、田面水の色は茶褐色を呈した。コドラートを用いて、7月及び 9 月 における雑草量を調査したところ、雑草をそのまますき込んだ対照区が、アゼナや夕 マガヤツリを中心とする水田雑草で覆われてしまうのに対し、ベッチをすき込んだ区 では雑草の発生は殆ど認められなかった（図3）。

ベッチすき込み区の湛水下での著しい雑草抑制作用が水溶性のアレロパシー成分に 基ずいているのかどうかを調べるため、寒天で固化した田面水の抑草活性について調 查したところ、水田から採取したアゼナの寒天上での生育は、対照区やクローバーを すき込んだ区とベッチ区の間に有為な差は認められなかった（図4）。感受性の高い レタスを検定植物として同様の実験を行ったが、やはりベッチ区の田面水には抑草活 性が認められなかった。

この事実から、ベッチすき込みによる水田雑草の抑制には、湛水条件下でのベッチ の急速な分解に伴う土壤の著しい還元化やベッチ成分の中でも水田表層の土㙵粒子に 強く吸着するアレロパシー成分が関係しているものと考えられる。

Fujihara, S., Y. Hanano and Y. Fujii: Weed growth regulation by hairly vetch (Vicia villosa ROTH.) in abandoned paddy fields. 


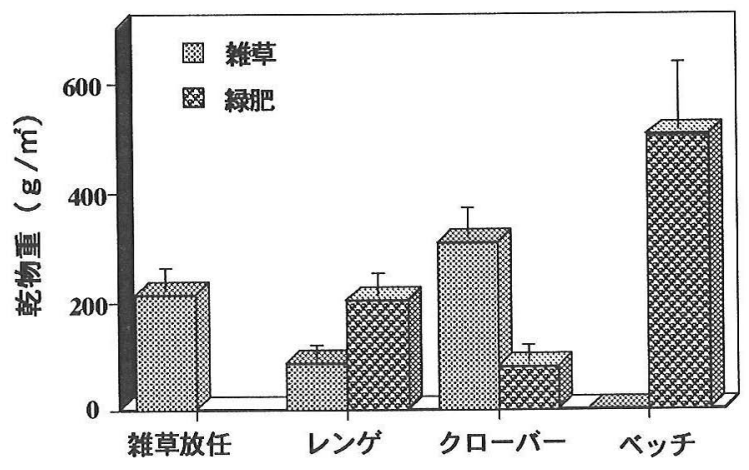

図 1 耕作放杽田におけるマメ科緑肥の雑草抑制効果

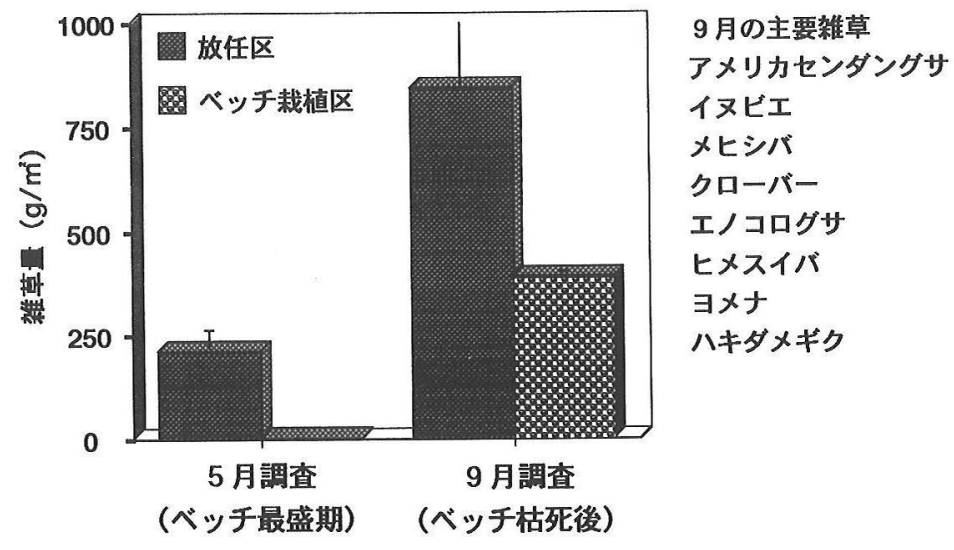

図 2 ベッチによる休耕田（畑条件放置）の雑草管理
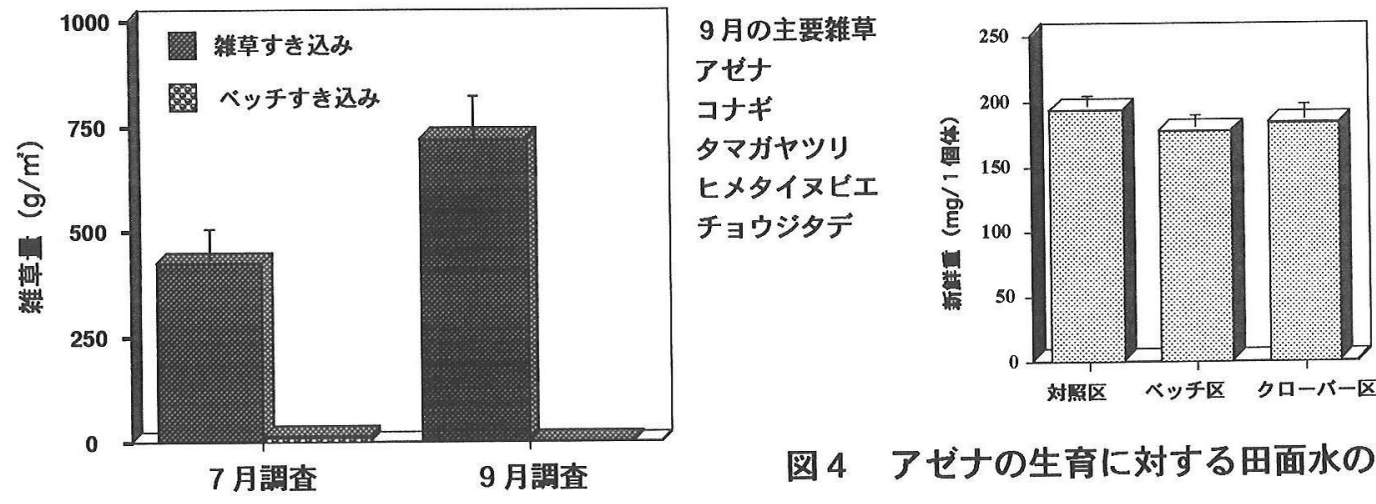

図4アゼナの生育に対する田面水の効果

図 3 ベッチすき込みによる水田雑草の抑制 